\title{
Synergies in merger \& acquisition: A case study of SMEs in Vietnam
}

\author{
Bui Hong Diep a and Tung Tran Anh ${ }^{b^{*}}$
}

${ }^{a}$ Ho Chi Minh City University of Food Industry, Vietnam

${ }^{b}$ Hong Bang International University, Vietnam

\begin{tabular}{ll}
\hline CHRON I C L E A T RACT \\
\hline
\end{tabular}

Article history:

Received: April 82020

Received in revised format: May

42020

Accepted: June 82020

Available online:

June 82020

Keywords:

$M \& A$

Synergies

SMES

Vietnam

\begin{abstract}
This paper aims to shed light on whether the Merger \& Acquisition (M\&A) among several cases create values for Vietnam small and medium enterprises (SMEs). Using 48 months of actual data to compare the pre- and post- merger performance, the study evaluates the impacts of the M\&A on business performance collected from HOSE stock exchange website. The result shows that out of 11 chosen key performance indicators (KPIs) and those selected firms only we have 2 KPIs with better results while 6 KPIs do not change and 3 KPIs are even worse after the M\&A. In addition, the finding indicated that very few actions were implemented and hence unsurprisingly, the M\&A outcomes did not really match with firms' original expectations. From the theory and the actual results of the analysis, the study provides a number of practical areas that companies should focus on to increase the chance of success for their M\&A.
\end{abstract}

\section{Introduction}

According to Cartwright and Schoenberg (2006), many top executives see M\&A as a key component of corporate strategy by offering opportunities for higher profitability, cost reductions and long-term growth. However, top executives seem to underestimate the risks involved in M\&A since according to Harvard Business Review, from $70 \%$ to $90 \%$ of M\&A deals fails to create the intended values. In Vietnam, the M\&A market has grown rapidly in the last 14 years. According to StoxPlus (2015), there are only less than $40 \mathrm{M} \& \mathrm{~A}$ deals in the Vietnam market with total transactions value of less than USD 0.5 billion in 2005 . However, by 2015 , total transactions value increased by more than 10 times to USD5.2 billion with 341 deals completed. Inbound M\&A into Vietnam accounted for $46 \%$ of M\&A deal value and totaled US $\$ 2.42$ billion whereas domestic M\&A had a total value of USD2.70 billion. As Vietnam focuses to attract more and more Foreign Direct Investments (FDI), it has become a very attractive place for M\&A. There are still many challenges with M\&A activities in Vietnam however. For example, Allen consulting firm mentioned several keys M\&A legal issues for foreign investors in Vietnam such as

- Lack of clear legal recognition, and track record of enforcement for issues in M\&A,

- Lack of detailed guidelines for M\&A of public companies,

- Equity investments in VND means currency exchange risk for foreign investor,

- Anti-trust issues can be a deal-breaker.

* Corresponding author

E-mail address: tungta@hiu.vn (T. T. Anh)

(C) 2020 by the authors; licensee Growing Science, Canada doi: $10.5267 / \mathrm{j} . j p m .2020 .6 .001$ 
According to Mr. Christopher Kummer - President of Institute of M\&A Association (IMAA), Swiss, the integration between the two companies post M\&A is a real challenge since the two merged companies have different strategies, culture and organization structure. In Vietnam, we can see many issues related to M\&A even between big names like Masan and Vinacafe, SHB and HabuBank, Decson and Binh Thien An, Bibica and Lotte, such as management boards of the two companies could not agree on business strategy after merger or management boards of the two companies could not agree on how the company should be run and who can make the decisions. Company like Tribeco even wanted to stop the company's operation after the merger (Jemison \& Sitkin, 1986; Sirower \& Sahni, 2006).

Besides, there are very limited Vietnamese literatures in this area to guide companies to implement successful M\&A (Vuong et al., 2009; Entezarkheir \& Moshiri, 2015; Vu Anh Dung, Dang Xuan Minh, 2012, Nguyen Thanh Lan, 2015). Moreover, there were many arguments arose that M\&A was neither an actual remedy for Vietnam SMEs firms to achieve the internationalization target nor increase business performance in domestic market. Using the synergy sources framework from Ross et al. (2010) and the practical M\&A guidelines from KPMG (1999), the authors would like to scientifically validate these arguments. Through this example, the author also recommends an approach that other companies in Vietnam could use to improve their M\&A results (Picot, 2002).

\section{Literature review}

\subsection{Concept of Merger and Acquisition}

Mergers and acquisitions are the situation when two companies are combined to achieve strategic and business objectives (Chatterjee \& Bourgeois, 2002). According to DePamphilis (2011), a merger is usually the mutual agreement by which two equal organizations merge to create a single entity whereas an acquisition normally refers to the situation where a much bigger organization takes over a smaller one. On the other hand, Coates (2014) from Harvard Law School and Ross et al. (2010) both divide M\&A into 3 types: merger or consolidation, asset purchases and stock purchases. In Vietnam, M\&A activities are governed by different laws including The Law on Enterprises in 2014, The Law on Investment in 2014, and The Law on Competition 2014.

\section{Types of Merger and Acquisitions}

When two organizations are within the same industry, the merger is called a horizontal merger. Related merger is when organizations that produce or sell products that share certain commonalities merge with each other (Kaplan \& Norton, 1992). Mergers between organizations operating in different stages in the same value chain are categorized as vertical mergers. The target company can also be a private company or a public company. Acquisition of public companies is often more publicized event in the media comparing to private companies (DePamphilis, 2011; Ismail et al., 2011). There are also domestic acquisitions, in which both the acquirer and the target companies are from the same country versus cross-borders acquisitions where the two companies come from different countries. An acquisition can also be "friendly", in other words, meeting the desires of the seller and the buyer, versus hostile (non-friendly) when the acquiring company buying significant portion of stocks of the acquired company against the wish of the acquired company. Besides according to Martynova and Renneboog (2006), a full acquisition is when the acquirer buys $100 \%$ of the ownership of the target company whereas in partial acquisitions, the acquirer only buys part of the ownership of the acquired company (Wang \& Moini, 2012).

\section{Objectives of Merger and Acquisitions}

According to Sudarsanam, (1995), there are two different perspectives for understanding the objectives the companies have for starting an M\&A: the maximization perspective of shareholders' wealth and the managerial perspective. In the maximization perspective of shareholders' wealth, the company decision to acquire another company is fully because companies look for ways to 
maximize the wealth of the shareholders. The maximization of the value of the shareholder takes place when the net present value of the investment is positive. The second perspective is the managerial perspective for conducting an M\&A, which focuses more on the motives of top executives in the company. These can be varied such as growth reasons, to use previous underemployed abilities and skills, risk diversification (Ansoff, 1958) and to evade being the ones being taken over.

\subsection{Synergy}

According to Burney (2008), the "Synergy" word originates from Greek and it means to work together. Synergy has been explained as "the whole is greater than the sum of its parts" or put it simply 1+1=3 (Sherman, 1998). In M\&A, synergy can be explained as - If 'Company A' merges with 'Company B', the value of merged entity called 'Company C' should be greater than the sum of the values of Company A and Company B (Johnson et al., 2015).

$\{\mathrm{V}(1)+\mathrm{V}(2)\}<\mathrm{V}(3)$ Where:

$\mathrm{V}(1)=$ Independent Value of Company A,

$\mathrm{V}(2)=$ Independent Value of Company B,

$\mathrm{V}(3)=$ Value of Merged Entity - Company B

$\Rightarrow$ Synergy $=\Delta V=V(3)-(V(1)+V(2))$

Various empirical studies show the successes or failures of merged companies. Petitt and Ferris (2013) in their study on M\&A and synergy found that when two companies enters into an M\&A transaction and synergies are apparent between them then there is high potential that value will be created and the M\&A can be a success. Grinblatt and Titman (2004) also suggest companies should only pursue an M\&A if the value of the acquirer and the target company when they operate as a single company is greater rather than sum of the values that individual ones can bring when operate independently. Godbole (2013) argues that Merger and Acquisition values actually come from synergy and for an M\&A to create its intended values, company management must find a way to create synergies between the two companies in the post-merger, integration phase. Not only the academic but also the major consulting companies talk about the same. For example, KPMG in its "Synergies: A business guide report" in 2011 also emphasized that "without synergies, an M\&A is unlikely to result in any significant incremental shareholder value". According to KPMG (2001), synergies are very important in M\&A as 1) It directly impacts the bidder price where normally, bidders would need to pay a premium to the acquiring company and this premium is normally calculated based on the additional values or synergies that the bidders think it can get from the deal. 2) Synergy is key to form the message that the successful bidder will make to deliver an effective communication to the stock market about the M\&A and 3) Synergy is also key for successful bidder to form a message to get buy-in from managers and employees of the acquiring and acquired companies.

\section{Sources of synergy}

According to Mallikarjunappa and Nayak (2007), synergies might come from more efficient management, improved production techniques, economies of scale and scope, redeployment of assets, resources combination or the exploitation of market power or any number of values enhancing mechanisms. According to Ross et al. (2010), value synergies is based on the incremental cash flow, which is the change in cash flow of the combined firm and the sum of the cash flow for two firms considered separately.

$$
\Rightarrow \text { Synergy }=\Delta C F=C F(3)-(C F(1)+C F(2))
$$


where: $\Delta$ Revenue, $\Delta$ Cost, $\Delta$ Tax respectively are the difference in the revenue, cost, tax of the combined firm versus the sum of the cash flow for two separate firms. $\Delta$ Capital requirement is the changes of fixed assets and net working capital. Consequently, Ross et al. (2010) suggested that M\&A synergy can be categorized into four main types as shown in below figure

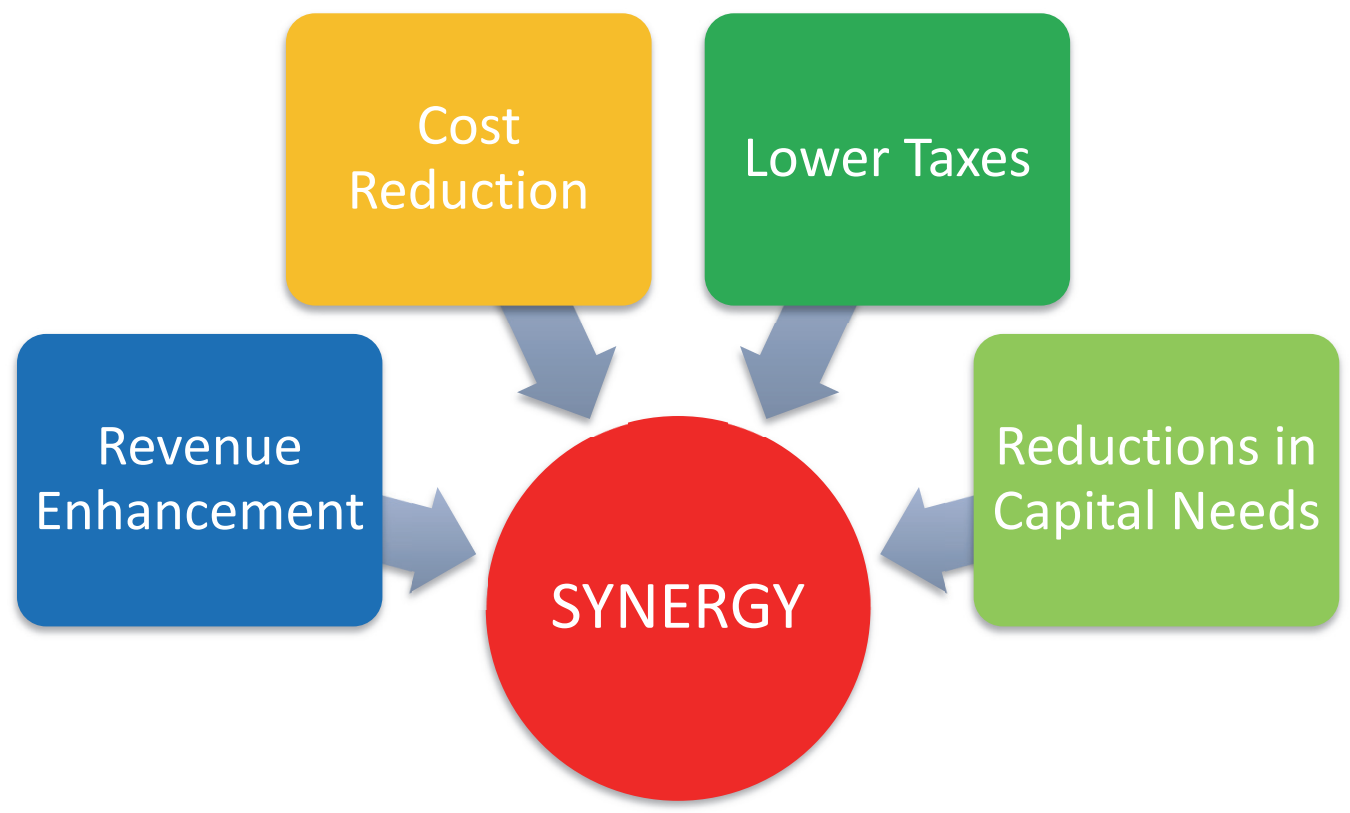

Fig. 1. Sources of synergy

\subsubsection{Revenue enhancement}

Increased revenue can come from using shared distribution channel or media or sales forces to sell for the products and brands of both the acquiring and acquired companies. With an increased market share, mergers can increase the market power of the acquiring company as it has more controls on prices or quantities within the market and thus increase the revenues. Vertical integration can also result in higher market power by increasing entry barriers and lowering input costs for the firm. (Sudarsanam, 2006-2007; Faulconbridge et al., 2008; Galpin \& Herndon, 2000; Srivastava \& Datta, 2002).

KPMG (1999) mentioned in their "Mergers and Acquisitions: Global Research Report" that "synergies are vital to the success of any merger or acquisition without them, an M\&A is unlikely to result in any significant additional growth in shareholder's value". They urge companies going into M\&A to have a clear understanding of what and where value can be obtained in revenue. Based on KPMG survey (1999) on over 700 cross border deals between the 2 years from 1996 to 1998, companies can actually focus on the following factors to increase revenue like in figure 4 : New market, new customer, cross-selling, marketing, sales force, new product, improved customer services, new distribution channels. 


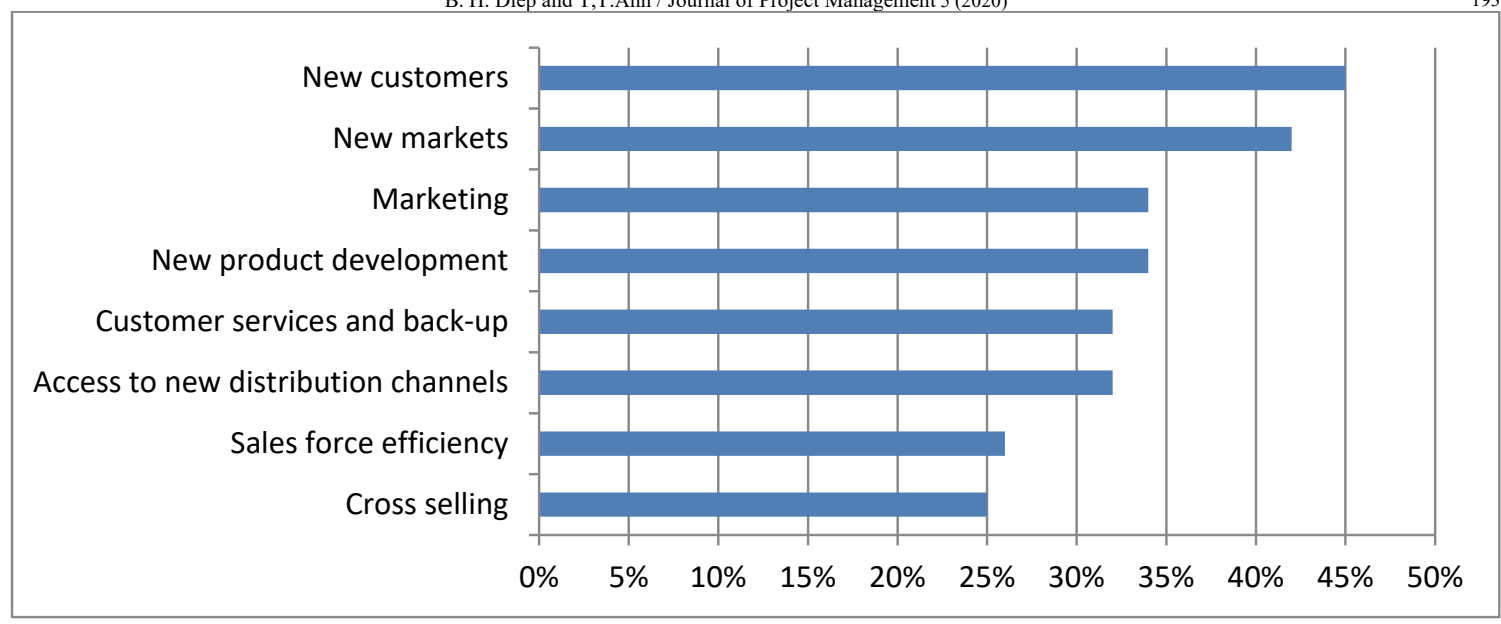

Fig. 2. Areas for increasing revenue

\subsubsection{Cost reduction}

Cost reduction involves streamlining the combined operations in such a manner that by joining functional activities, the acquirer and acquiring companies can reduce costs by avoiding duplication in marketing, research and development as well as optimize costs related to sales, human resource, Finance, Admin and other overhead costs. Operational cost synergies in terms of economies of scale can also be achieved by spreading the fixed costs over increasing production volumes and hence lowering the average unit cost. Besides, a merger can also help to reduce excess capacity and the acquirer can therefore, adjust supply levels to match demands to optimize costs. Last but not least, merger can also lead to a stronger buyer power to lower input prices (DePamphilis, 2011; Marks \& Mirvis, 2010). By reducing costs the combined firm can improve its margins and thereby boost profits given that the price and sales volumes are unchanged. For example, in the airline industry, when Kingfisher Airlines acquired Deccan Airways and Jet Airways acquired Sahara Airlines, both were expecting to achieve substantial savings through operations synergies such as reduction in the combined number of flights on the same routes, sharing of commercial and ground handling staff, rationalization of routes, reduction in the combined number of airplanes in use and so on (Gupta, 2012; Dringoli, 2016; Grotenhuis, 2009; Sevenius, 2003). Similar to synergy in revenue, KPMG (1999) also reports the key areas for potential cost synergies that companies can get from the following factors: Headcount reductions, buying and merchandising, supply chain, procurement, manufacturing, warehousing and distribution, new product development, R\&D in Fig. 3. These factors are chosen and also grouped into 5 main factors as below:

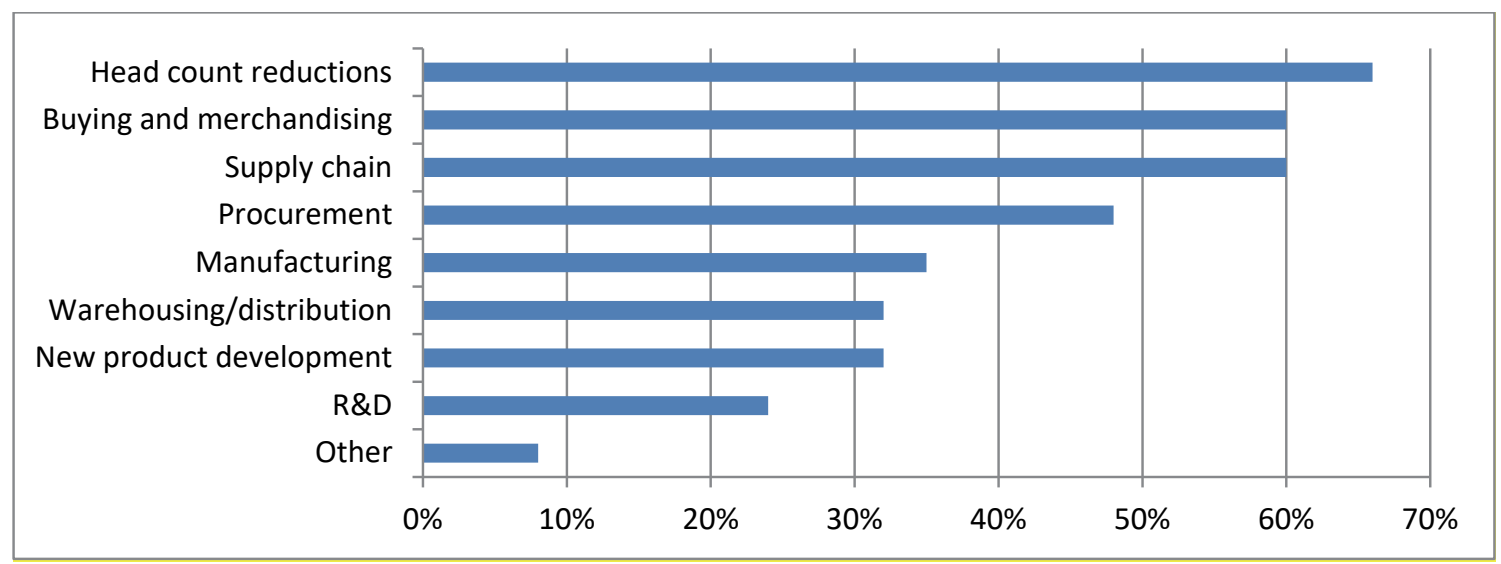

Fig. 3. Areas for saving cost 


\subsubsection{Lower taxes}

According to Gupta (2012), tax synergy might occur when merging a loss-making company with a profitable one so that the merged company can write-off accumulated losses of the loss-making company against the profits of the profit-making company. Tax synergy can also arise in crossborder M\&A, when the combined company might take the opportunity to optimize their tax pay by allocating more works and costs to the new country should the tax rate is lower there. According to Auerbach and Reishus (1987), there are clear tax benefits available at the corporate level in the form of stepped-up asset bases and the increased utilization of tax losses and tax credits. Even at stakeholder level, tax benefits might be available through an M\&A deal for example, shareholders of acquired companies might receive payments when selling their shares which are at a much lower tax rate than the stakeholders normal income tax rate or even in some cases non-taxable (Auerbach \& Reishus, 1987)

\subsubsection{Reductions in capital investment}

M\&A can help to reduce the combined investment needed by the two firms According to Gupta (2012), reduction in capital investment synergy involves combining both the acquirer and target companies' Balance sheets to achieve a better gearing ratio or a reduction in the weighted average cost of capital (WACC). Companies can create value through merger and acquisition by investing the capital they raise from investors to generate future cash flows (Koller, 2009). This financial synergy through mergers and acquisitions can help to lower the cost of capital and therefore, increase company value. In unrelated acquisition, the acquirer can acquire another company with un-related cash flows and thereby reduce risk by diversifying their financials (Schall \& Higgins, 1975). Mewes (2015) also suggests smaller companies generally have to pay a premium when borrowing money relative to larger companies however, when two mid-sized companies merge, they can lower their combined cost of capital more than they could individually. An example is the merger of Reliance Petrochemicals Limited (RPL) with the Reliance Industries Limited (RIL) in 1991-92 by "lowering the cost of capital so as to allow them to invest in capital intensive projects with various refineries" (Gupta, 2012; Haspeslagh \& Jemison, 1991).

\section{Methodology}

There are two common research approaches, i.e. quantitative vs. qualitative and this research uses both research approaches in order to insights into the M\&A deal among SMEs in Vietnam. In quantitative method, First, the author collects financial performance data from audited financial statements as well as from various internal management reports. Data during the 4 period from 2014 to 2018 were collected to compare the performance before and after M\&A. The author runs a paired sample T-test on these data to validate if there was any significant change in SMEs performance before and after the M\&A. Due to confidentiality; a number of data presented in this thesis has been normalized reason show only the percentage comparison to a base year before M\&A. Second, the author also performs in depth interviews with key personnel in selected firms. In-depth interviews are personal and unstructured and aim to identify the participant's emotions, feelings, and opinions about the M\&A. The author also used content analysis, which is the type of research where gathered data is categorized in themes and sub-themes so that they can be compared (Moore et al., 2006), to analyze the interviewed data. An advantage of this data analysis approach is the data collected could be simplified and reduced, while at the same time producing results that may then measure using quantitative techniques. On the other hand, Qualitative Research is primarily exploratory. It is used to understand underlying reasons and motivations. It helps to provide problem insights into the problem or develop hypotheses for potential quantitative research. In contrast to quantitative analysis, qualitative outcomes are normally not quantifiable or measurable. Qualitative analysis is more appropriate for small data samples situation. Its advantage is that "it offers a complete description and analysis of a research subject, without limiting the scope of the research and the nature of 
participant's responses" (Collis \& Hussey, 2003). However, because the outcomes of qualitative research can be based on from researcher's personal judgments and interpretations therefore, a drawback of this research approach is the quality is heavily based on the skills and abilities of researchers. Also, according to Bell (2005), there are risks that the results of qualitative research might not reflect all the opinions of a wider population as the approach is more appropriate for small data sample. In this paper, qualitative method is used to clarify the concepts like M\&A and synergy as well as to analyze the M\&A case.

\section{Findings}

The author runs a paired sample T-test on the data to validate whether there was any significant change in performance after the M\&A. The significance level is higher than 0.05 , by conventional criteria, this difference is considered to be not statistically significant where as if the significance is smaller than 0.05 , this difference is considered to be statistically significant.

\subsection{Result of Synergy indicators}

\section{Revenue enhancement}

Those table below illustrated the pair-sample T-test of revenue enhancement after M\&A

Table 1

Paired sample T-test SMEs revenue growth

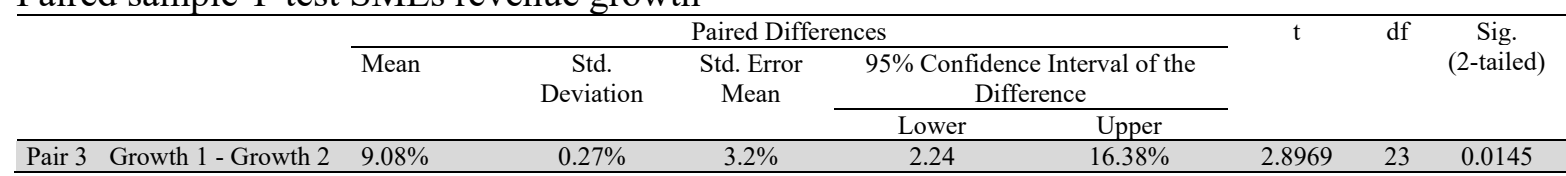

Table 2

Paired sample T-test SMEs revenue per employee

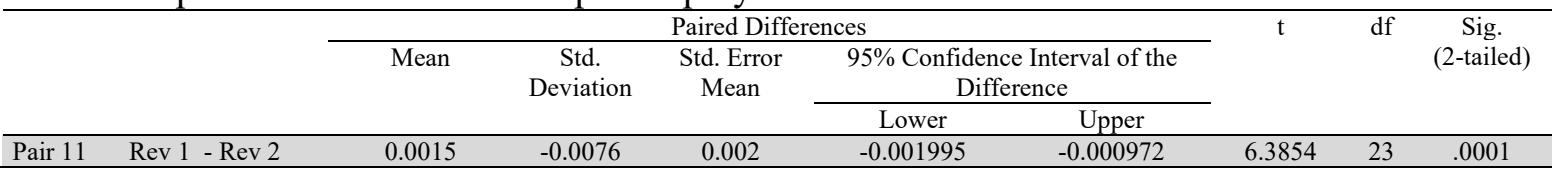

Table 3

Paired sample T-test SMEs customer satisfaction

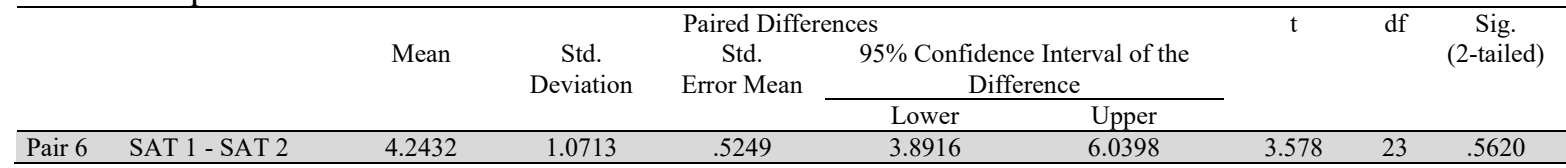

Table 4

Paired sample T-test SMEs ROE

\begin{tabular}{|c|c|c|c|c|c|c|c|c|c|}
\hline & & \multicolumn{5}{|c|}{ Paired Differences } & \multirow[t]{3}{*}{$\mathrm{t}$} & \multirow[t]{3}{*}{$\mathrm{df}$} & \multirow{3}{*}{$\begin{array}{l}\text { Sig. (2- } \\
\text { tailed) }\end{array}$} \\
\hline & & \multirow[t]{2}{*}{ Mean } & \multirow[t]{2}{*}{$\begin{array}{c}\text { Std. } \\
\text { Deviation }\end{array}$} & \multirow[t]{2}{*}{$\begin{array}{l}\text { Std. Error } \\
\text { Mean }\end{array}$} & \multicolumn{2}{|c|}{$\begin{array}{l}95 \% \text { Confidence Interval of the } \\
\text { Difference }\end{array}$} & & & \\
\hline & & & & & Lower & Upper & & & \\
\hline Pair 1 & ROE 1 - ROE 2 & $-0.45 \%$ & $0.17 \%$ & $1.10 \%$ & $-0.7561 \%$ & $-0.1389 \%$ & -.6414 & 23 & 0.7097 \\
\hline
\end{tabular}

Table 5

Paired sample T-test SMEs ROA

\begin{tabular}{|c|c|c|c|c|c|}
\hline \multirow{3}{*}{ Mean } & \multicolumn{3}{|c|}{ Paired Differences } & \multirow[t]{3}{*}{$\mathrm{t} \quad \mathrm{df}$} & \multirow{3}{*}{$\begin{array}{c}\text { Sig. } \\
\text { (2-tailed) }\end{array}$} \\
\hline & $\begin{array}{l}\text { Std. Devia- } \\
\text { tion }\end{array}$ & $\begin{array}{l}\text { Std. Error } \\
\text { Mean }\end{array}$ & $\begin{array}{l}\text { 95\% Confidence Interval of the } \\
\text { Difference }\end{array}$ & & \\
\hline & & & Upper & & \\
\hline
\end{tabular}

\begin{tabular}{llllllllll}
\hline Pair 2 & ROA 1 - ROA 2 & $-0.03547 \%$ & $0.42407 \%$ & $0.08656 \%$ & $-0.21454 \%$ & $0.14360 \%$ & -.410 & 23 & .686
\end{tabular}




\section{Cost reduction}

The below indicators were used to analyze whether firms achieved cost reduction synergies after $\mathrm{M} \& \mathrm{~A}$

Table 6

Paired sample T-test SMEs Gross Profit

\begin{tabular}{|c|c|c|c|c|c|c|c|c|}
\hline & \multicolumn{5}{|c|}{ Paired Differences } & \multirow[t]{3}{*}{$\mathrm{t}$} & \multirow[t]{3}{*}{$\mathrm{df}$} & \multirow{3}{*}{$\begin{array}{l}\text { Sig. (2- } \\
\text { tailed) }\end{array}$} \\
\hline & \multirow[t]{2}{*}{ Mean } & \multirow[t]{2}{*}{$\begin{array}{c}\text { Std. } \\
\text { Deviation }\end{array}$} & \multirow[t]{2}{*}{$\begin{array}{l}\text { Std. Error } \\
\text { Mean }\end{array}$} & \multicolumn{2}{|c|}{$\begin{array}{l}\text { 95\% Confidence Interval of the } \\
\text { Difference }\end{array}$} & & & \\
\hline & & & & Lower & Upper & & & \\
\hline Pair 4 GPM 1 - GPM 2 & $-1.02043 \%$ & $1.99942 \%$ & $0.40813 \%$ & $-1.86471 \%$ & $-0.17615 \%$ & -2.500 & 23 & .020 \\
\hline
\end{tabular}

Table 7

Paired sample T-test SMEs EBIT/Sales

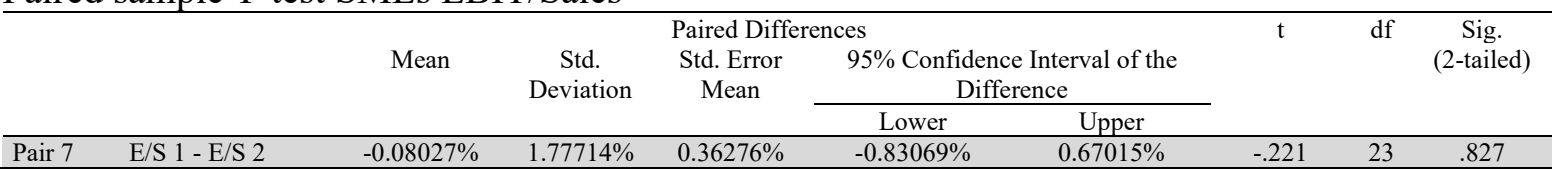

Table 8

Paired sample T-test SMEs Operating Ratio

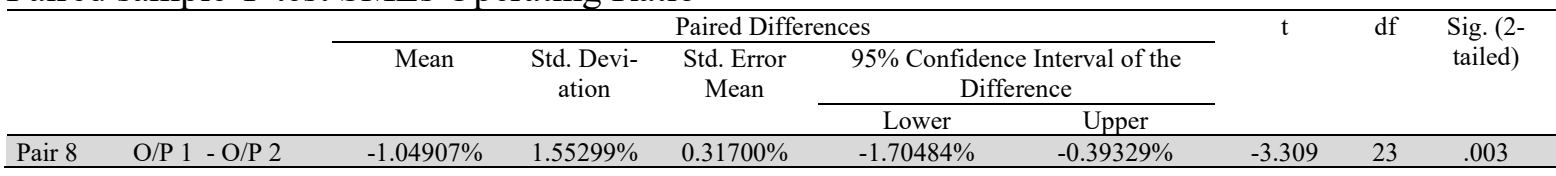

\section{Reduction in capital needs}

Table 10

Paired sample T-test SMEs Debt-to-Equity

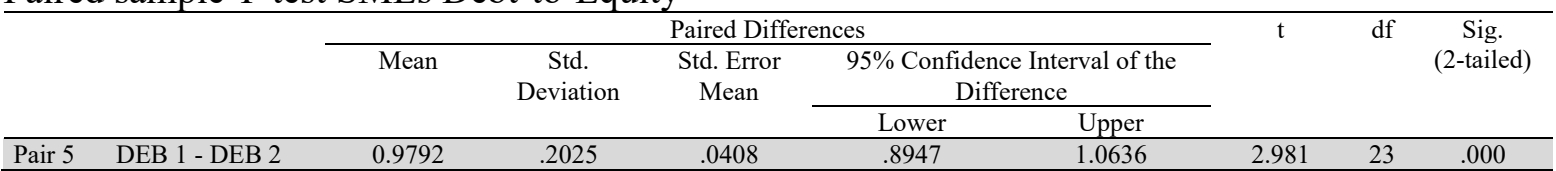

Table 11 summarizes the results of paired sample t-test results on the 10 KPIs for SMEs performance before and after M\&A

\section{Table 11}

The summary of synergy indicators before and after M\&A - Pair sample t-test results

\begin{tabular}{llll}
\hline Number & Area & Indicators & Results \\
\hline 1 & & Revenue growth rate & Worst \\
2 & & Revenue per employee & No change \\
3 & \multirow{4}{*}{ Revenue enhancement } & Customer satisfaction score & No change \\
4 & & Customer survey on M\&A deal & No change \\
5 & & ROA & No change \\
6 & & ROE & No change \\
\hline 7 & & Gross profit & Better \\
8 & Cost reduction & Operating Ratio: Opex cost / Sales & No change \\
9 & & EBIT / Sales & Worst \\
\hline 10 & & Debt to equity ratio & Better \\
\hline
\end{tabular}

It can be seen from the results of the quantitative analysis in the previous section that those selected firms achieved no revenue increment synergies (out of 6 KPIs, 1 KPI worse and 5 KPIs unchanged) and very little cost reduction in synergy (Out of 3 KPIs, 1 KPI better, 1 KPI unchanged and 1 KPI worsen). Our hypothesis is that firms got this result because they haven't done much in terms of 
creating synergy in this M\&A and we will validate that based on the sources of synergy framework and the KPMG practical guideline explained in literature review part.

\section{Conclusion and Recommendation}

As can be seen from the quantitative and qualitative analysis, we can see that those cases of M\&A are far away from meeting the original expectations that the two companies have. The key reasons are because they haven't done much in term of synergy creation both:

- Pre M\&A: No planning on how to create synergies from the M\&A

- After M\&A: Limited actions to create synergies in almost all potential areas.

Companies can use the sources of synergy as a framework to review integration process in M\&A deal, a demonstration of how this could be done is shown with the SMEs case study.

Consulting firms like KPMG suggest that companies should set up a cross functional project team to plan then execute the plan following M\&A annoucement to realise synergies (KPMG 2009). Integration project planning and execution should go hand in hand with synergy evaluation as a key to merger success. Through project plan, companies should work out exactly how synergies will be attained, and also how the combined business will be stabilized to preserve current value. KMPG reports that companies prioritized pre-deal integration project planning are $13 \%$ more likely than average to have a successful deal. Companies should remember they only have a 'honeymoon' period of some 100 days after deal completion to take hold of the business and begin realizing benefits.

The author strongly recommends that SMEs to setup a project team to implement required actions to create synergy. They should first review the different areas of synergies to see which ones are more relevant for them. The author recommends the below 4 areas as the most relevant and valueable for SMEs to focus on first due to their potential values as well as the easiness to implement:

a. Redudant positions: Although this is a very people sensitive activity, with determination, SMEs's management can implement this quite quickly as compared to other areas of synergy opportunities. SMEs management should note that they might never satisfy all stakeholders wishes but they need to ensure all the views from different stakeholders are taken into consideration i.e. Central Group owner, SMEs owner, management staffs, employees etc. For impacted stakeholders, actions should be planned upfront to minimise impacts on the overall project.

b. Sourcing consolidation: This is also another easy area for SMEs to look in to. They can form a centralised Sourcing team to review and compare all category of spending in both SMEs and Central Group Vietnam companies in order to consolidate and generate savings from optimising these spendings. In term of product procurement, SMEs should combine with Central Group when negotiating with product vendors such as Samsung, LG, Sony, etc ... for a lower price. This could be a competitive advantage for SMEs compared to other competitors in Vietnam market, who don't have such a big partner to increase its negotiation power.

c. Rationalize distribution centers: In the current electronic home appliance market in Vietnam, SMEs should continue to invest to open new stores in appropriate new locations if they don't want to be beaten by competitors like thegioididong. Additional capitals from M\&A should be utilized instead of keeping idle. They should also continue to collaborate with other Central Group subsidiaries like BigC Vietnam to get the best location for its stores. 
d. Back-office consolidation: SMEs should look at re-engineering business process from endto-end to not only remove duplicated processes but also to take advantages of the best practices from the two companies. This is a big, challenging project but if implemented successful, would bring significant values for SMEs.

\section{References}

Allen consulting (2016). Ten key M\&A legal issues for foreign investors in Vietnam. at http://www.allens.com.au/pubs/pdf/asia/Vietnam-MA-170629.pdf

Ansoff, H. I. (1958). A model for diversification. Management Science, 4(4), 392.

Atradius (2016) at https://atradiusdutchstatebusiness.nl/en/publications/top-eight-most-promisingmarkets-of-2016-.html

Sherman, A. J. (2005). Mergers and Acquisitions from A to Z (2nd ed). Saranac Lake:AMACOM.

Burney, A. (2008). Inductive and deductive research approach. Department of Computer Science, University of Karachi, Pakistan, 22.

Cartwright, S., \& Schoenberg, R. (2006). 30 years of mergers and acquisitions research: Recent advances and future opportunities. British Journal of Management, 17(S1), S1-S5.

Chatterjee, S., \& Bourgeois, L. J. (2002). A Framework for Acquisition Success: Post-Acquisition Resource Interactions. Batten Institute, Darden Graduate School of Business, University Of Virginia.

Corporate Finance Institute (2015). What are M\&A Synergies? https://corporatefinanceinstitute.com/resources/knowledge/valuation/mergers-acquisitions-masynergies/

Deloitte (2016). Retail in Vietnam Emerging market, emerging growth. at http://www.iberglobal.com/files/2016/vietnam_retail.pdf

Deloitte (2015). Integration Report 2015 Putting the pieces together. at https://www2.deloitte.com/content/dam/Deloitte/no/Documents/mergersacqisitions/integration-report-2015.pdf

DePamphilis, D. (2011). Mergers, acquisitions, and other restructuring activities: An integrated approach to process, tools, cases, and solutions (5th Edition). Amsterdam: Academic Press.

Dringoli, A. (2016). Merger and Acquisition Strategies: How to Create Value. Edward Elgar Publishing.

Entezarkheir, M., \& Moshiri, S. (2015). Merger induced changes of innovation: Evidence from a panel of US firms. Unpublished paper, Huron University College, Western University.

Faulconbridge, J., R., Hall, S., \& Beaverstock, J., V., (2008). New Insights into the Internationalization of Producer Services: Organizational Strategies and Spatial

Galpin, T. J., \& Herndon, M. (2000). The complete guide to mergers and acquisitions. San Francisco: Jossey-Bass Publishers.

Godbole, P. G. (2013). Mergers, acquisitions and corporate restructuring. Vikas Publishing House.

Grinblatt, M., \& Titman, S. (2004). Financial markets and corporate strategy. Mc Graw Hill.

Grotenhuis, F. D. (2009). Mergers and acquisitions in Japan: Lessons from a Dutch-Japanese case study. Global Business and Organizational Excellence, 28(3), 45-54.

Gupta, P. K. (2012). Mergers and acquisitions (M\&A): The strategic concepts for the nuptials of corporate sector. Innovative Journal of Business and Management, 1(4), 60-68.

Haleblian, J., Devers, C. E., McNamara, G., Carpenter, M. A., \& Davison, R. B. (2009). Taking stock of what we know about mergers and acquisitions: A review and research agenda. Journal of Management, 35(3), 469-502.

Haspeslagh, P. C., \& Jemison, D. B. (1991). Managing acquisitions: Creating value through corporate renewal (Vol. 416). New York: Free Press.

Ismail, T. H., Abdou, A. A., \& Annis, R. M. (2011). Review of literature linking corporate performance to mergers and acquisitions. The Review of Financial and Accounting Studies, 1(1), 89104. 
Jemison, D. \& Sitkin, S. (1986). Corporate acquisitions: A process perspective. The Academy of Management Review, 11(1), 145-163.

Johnson, Y., Ernest, K., \& Samuel, A. (2015). The impact of mergers and acquisitions on service quality of banks in Ghana: Case study of Eco Bank and Access Bank Ghana. International Journal of Business and Management, 10(12), 167 -180.

Kaplan, R. S., \& Norton, D.P. (1992). The Balanced Scorecard: Measures that Drive Performance, Harvard Business Review, January-February, 71-79.

Koller, T., Goedhart, M., Wessels, D., \& Copeland, T. E. (2009). Valuation: Measuring and managing the value of companies (5th ed.). Hoboken, N.J.: John Wiley \& Sons, Inc.

Kathryn Rudie Harrigan (2012). The Synergy Limitation Paradox

KPMG (1999). Mergers and Acquisitions: Global Research Report at http://people.stern.nyu.edu/adamodar/pdfiles/eqnotes/KPMGM\&A.pdf

KPMG (2001), Synergies: A business guide http://www1.american.edu/academic.depts/ksb/finance_realestate/rhauswald/fin673/673mat/K PMG\%20\%282001\%29,\%20Synergies\%20Guide.pdf

L.E.K consulting (2016). Mergers \& Acquisitions: What Winners Do to Beat the Odds. https://www.lek.com/sites/default/files/L.E.K._Mergers_Acquisitions-

What_Winners_Do_to_Beat the_Odds.pdf

Martynova, M., \& Renneboog, L. (2006). Mergers and acquisitions in Europe. Advances in corporate finance and asset pricing, 13-75.

Marks, M. L., \& Mirvis, P. H. (2010). Joining forces: Making one plus one equal three in mergers, acquisitions, and alliances. John Wiley \& Sons.

Mayer Brown consulting, 2012 at https://m.mayerbrown.com/Files/Publication/5bf9d1aa-ac4940db-adfd-d5cab9235df5/Presentation/PublicationAttachment/14e59549-5588-4aa1-95cbe45a2e52256a/12199.pdf

McKinsey (2010). A McKinsey perspective on value creation and synergies at https://www.mckinsey.com/client_service/organization/latest_thiNguyen

Kiming/ /media/D74F0B9DCDAB4EAE918D2D578E7C7AF7.ashx

Mitch Duckler (2016). Driving Organic Growth - http://www.fullsurge.com/resources/drivingorganic-growth

Moore, D. S., Notz, W. I., \& Notz, W. (2006). Statistics: Concepts and controversies. Macmillan.

NIVEN P.R. (2006). Balanced scorecard step-by-step: Maximizing performance and maintaining results. Hoboken: John Wiley \& Sons. 318p.

Nguyen Thanh Lan (2015) - Hoạt động mua bán và sáp nhập trong lĩnh vực bất động sản Việt Nam - Nhìn từ các thương vụ điển hình

Picot, G. (2002). Handbook of international mergers and acquisitions: Preparation, Implementation and Integration. New York: Palgrave Macmillan,

Vuong, Q. H., Tran, T. D., Nguyen, T. C. H., \& Ha, C. (2009). Mergers and acquisitions in Vietnam's emerging market economy, 1990-2009. Centre Emile Bernheim Research Institute in Management Sciences.

Ross, S. A., Westerfield, R., Jaffe, J. F., \& Jordan, B. D. (2009). Corporate finance: Core principles \& applications. McGraw-Hill/Irwin.

Saigon online, 2015 - "M\&A - Thách thức và cơ hội" at http://www.sggp.org.vn/xuctiencongnghiep/2015/3/378051/

Schall, L. D., \& Higgins, R. C. (1975). Corporate bankruptcy and conglomerate merger. The Journal of Finance - LA English, 30(1), 93.

Srivastava, R. P., \& Datta, D. K. (2002). Evaluating mergers and acquisitions: A belief function approach. In Belief Functions in Business Decisions (pp. 222-251). Physica, Heidelberg.

Sudarsanam, S. (1995). The essence of mergers and acquisitions. Hemel Hampstead: Prentice Hall.

Sudarsanam, S. (2006-2007). Creating value from mergers and acquisitions: The challenges : An integrated and international perspective (5th Edition). Harlow: FT Prentice Hall.

Sevenius, R. (2003). Företagsförvärv - en introduction. Lund, Studentlitteratur. 
Sirower, M. L., \& Sahni, S. (2006). Avoiding the "synergy trap": practical guidance on M\&A decisions for CEOs and Boards. Journal of Applied Corporate Finance, 18(3), 83-95.

StoxPlus (2015). VIETNAM M\&A REPORT 2015

Thomson Reuters (2012). M\&A Review. Available at www.thomsonreuters.com, last date of search: 29 December 2013.

UNACTAD, U. N. (2012). 2012 World Investment Report. Available at http://unctad.org/en/Pages/DIAE, last date of search: 6 May 2013.

Wang, D., \& Moini, H. (2012). Performance assessment of mergers and acquisitions: Evidence from Denmark. E-Leader Berlin, (2008), 1-15.

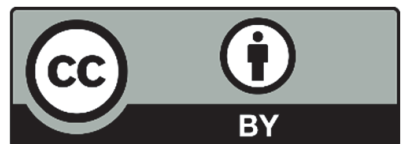

(C) 2020 by the authors; licensee Growing Science, Canada. This is an open access article distributed under the terms and conditions of the Creative Commons Attribution (CC-BY) license (http://creativecommons.org/licenses/by/4.0/). 